\title{
袋状ネットの利用による短梢せん定栽培ブドウの鳥獣害対策の省力化
}

\author{
東 暁史 $*$ ・薬師寺 博・児下佳子 \\ 独立行政法人農業・食品産業技術総合研究機構果樹研究所ブドウ・カキ研究拠点 739-2494 広島県東広島市安芸津町
}

\section{Prevention of Bird and Animal Damage to Grapes Using a New Labor-saving Net}

\author{
Akifumi Azuma*, Hiroshi Yakushiji and Yoshiko Koshita \\ Grape and Persimmon Research Station, National Institute of Fruit Tree Science, NARO, Akitsu, Higashihiroshima, Hiroshima 739-2494
}

\begin{abstract}
We designed a new labor-saving net aimed at preventing birds and animals from damaging bunches of table grapes on spurpruned grapevines. The bag-like nets perfectly cover only the grape bunches, allowing many bunches to be quickly protected all at the same time; moreover, because the nets are easily hung beneath the trellis, workers do not need to use stepladders or other such implements. We investigated the efficiency of working with these prototype nets and the degree of protection from bird and animal damage. The time required to install the prototype nets was $32.8 \%$ of the time required to install standard commercial netting. We confirmed that the prototype nets almost completely prevented bird and animal damage in two cultivars. Furthermore, there were no undesirable effects of the prototype nets on fruit quality. These findings suggest that using this type of net is an effective method of preventing bird and animal damage to grape bunches on spur-pruned grapevines.
\end{abstract}

Key Words : animal pests, bird pests, fruit tree, light labor, physical barrier

キーワード : 物理的防除, 害鳥, 害獣, 果樹, 軽労化

\section{緒言}

鳥獣による農作物への被害は, 農山村地域では常態化し, 都市近郊での被害も増加している. 2008 年には鳥獣被害防 止特措法（農林水産省, 2008）が施行されるなど，鳥獣に よる農作物の被害対策は農林水産分野の重要な課題となっ ている，ブドウ栽培に拈いても，収穫前の果実がカラスや ヒヨドリ，八クビシンなどによって食害される例が報告さ れて打り（鈴木・吉永, 1999), 効果的な対策が求められて いる.

農作物の鳥獣害対策として, 物理的防除法 (侵入防止柵, 電気柵, 防鳥ネット), 德覚的防除法 (爆音機, 鳥の悲鳴や 警戒音), 視覚的防除法 (か力し, 目玉模様), 嗅覚的防除 法 (忌避剤) などがあり（池内ら，2005; 松岡，1989; 中村・ 岡ノ谷, 1992; 中村 - 横山, 1995; Shirota 5，1983; 鈴木・ 吉永, 1999; 米田ら, 2005), ブドウ産地においてもいくつ か利用されている.

しかし，これら従来技術による鳥獣害の防除には問題点 も多い. すなわち, 聴覚的防除法, 視覚的防除法, 嗅覚的 防除法は, 一時的な効果はあるものの, 短期間で慣れを生 じることが多く（鈴木・吉永, 1999), 持続的な効果が得ら

2009 年 11 月 16 日 受付. 2010 年 4 月 23 日 受理.

* Corresponding author. E-mail: azumaa@affrc.go.jp
れる方法は確立されていない．物理的防除法は最も効果的 であるが，侵入防止柵や電気柵の設置，維持管理には多大 な労力を要する.さらに, 被害地域全体で適切な設置方法 を検討しなければ，十分な効果は得られない。

果樹に拈いてブドウは，平成 18 年度における $10 \mathrm{a}$ 当た りの労働時間が約 460 時間（農林水産省生産局, 2009）と, 最も長い樹種の一つであるとともに，生産者の高齢化が進 行している. そのため，管理作業の省力化は重要な課題と なっている，近年，ブドウ栽培に拈いて，管理作業の簡便 性などから短梢せん定栽培法，ならびに短梢せん定栽培の 一つで作業性がさらに改良された新短梢せん定栽培法が注 目されている（小川，2001; 山梨県果樹園芸会，2007）。短 梢せん定栽培は，果房が一列に並ぶため管理作業を効率良 く行うことができ，せん定や新梢管理も単純で，新規就農 者や高齢者でも取組みやすい方法である。しかし，鳥獣害 対策については，これまでと同様にブドウ棚上および棚下 への防鳥ネットの被覆と電気柵の併用が, 露地栽培を中心 に一般的に行われている. 棚上への防鳥ネットの設置には, 脚立などを用いた高所作業が必要であるが，重心動摇の大 きい高齢者にとっては特に危険であり（前川ら，1998）, 少 人数での被覆が困難であるなど, 多大な労力を要している. さらに，ネットの設置が不完全であると，十分な効果が得 られず，着脱時にネットの引っ掛かりなどによる枝葉の損 傷が生じる点，資材の再利用が困難な点も問題である。 ま 
た，鳥獣害対策を目的とした防鳥ネットと電気柵の併用は， 栽培管理の作業性を低下させる恐れがある。これらの理由 から，着脱が簡便で，防鳥獣効果の高い資材の開発が強く 望まれている。

そこで，著者らは短梢せん定栽培ブドウを対象として， 着脱が容易で鳥獣害を効果的に防ぐ，袋状の防鳥獣ネット （以下袋状ネット）を考案した（東ら，2009）。本試験では， 袋状ネットによる取付け作業の省力効果, 鳥獣害の防止効 果，ならびに果実品質に及ぼす影響を調査した。

\section{材料および方法}

\section{1．袋状ネットによる取付け作業の省力評価試験}

果樹研究所ブドウ・カキ研究拠点で栽植中の 5 年生露地 植え新短梢せん定栽培 ‘ピオーネ’（一文字型整枝法）を 3 樹供試した. 主枝は片側 $6 \mathrm{~m}$ の 2 本主枝とし, 結果枝は $1.5 \mathrm{~m}$ で摘心した．着房数は概ね 1 結果枝当たり 1 果房と した. 本試験で使用した袋状ネットの模式図を第 1 図 A に 示した。 その特徴は，耐久性のあるポリエチレン製のネッ

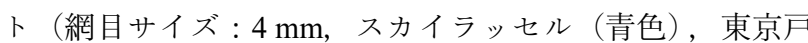
張）をブドウ果房のみが覆われるよら袋状にすることで，

A

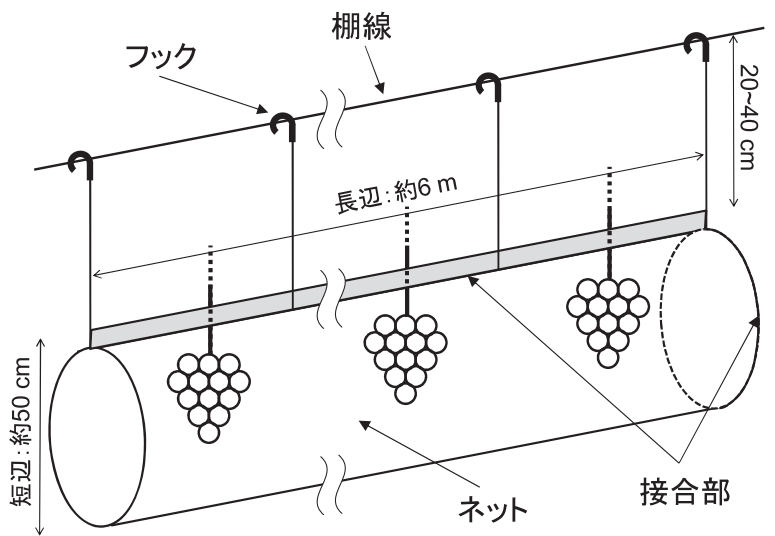

B

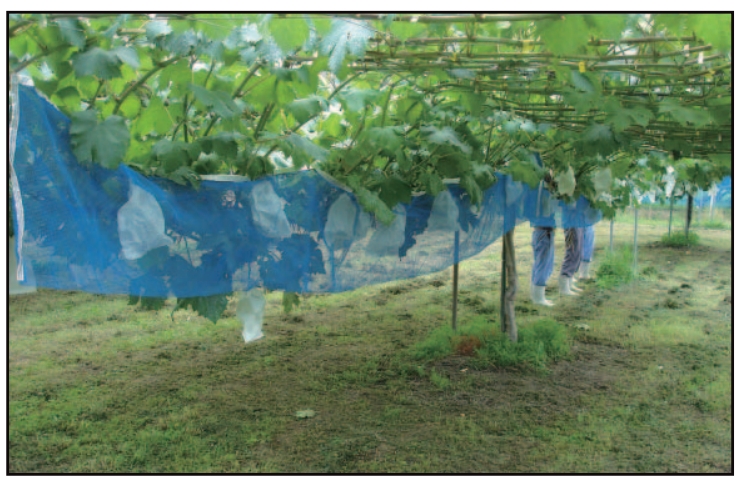

第1図袋状ネットの模式図（A）と新短梢せん定栽培 ‘ピ オーネ’ (一文字型整枝法) に打忊る実施例 (B) 模式図 (A) は, 短辺を接合する前の開口した状態を示す
短時間で多数の果房が一度に保護される点である. 本試験 に拈けるネットの長辺の長さは約 $6 \mathrm{~m}$, 短辺の長さは設置 完了時に約 $50 \mathrm{~cm}$ となるようにした。 また，棚下にネット を吊るすためのステンレス製のフック（ミニクリップ，水 本機械製作所）を長辺側に装着することで，着脱時におけ る脚立の使用を不要とした。ささらに，接合部にはナイロン 製の面ファスナー（幅：16 mm, マジックテープ, クラレ ファスニング）を用いることで，袋の開閉を容易とし，果 房の管理と収穫がどの位置からでも可能となるようにし た. 袋状ネットの取付け手順は以下の通りである. (1)ネッ トの一方の長辺に装着されたフックを，一列に並んだ果房 に沿って棚線に引っ掛け, ネットを棚下に固定する. (2)ネッ 卜は果房に近接して下方に垂れ下がった状態となるので, 一列に並んだ果房を包むように他方の長辺を持ち上げる.

(3)ネットの長辺側の外周に装着された接合部で, 列状に並 んだ果房上部の穂軸を挟んで相互に接合する（第 1 図 A).

(4)短辺の外周に装着された接合部を相互に接合することに より，ネットは袋状となり，果房はネット内に被覆される (第 1 図B).

取付け時間の調査は 2008 年 7 月 8 日に行った。試験区 は，袋状ネット 4 張を用いて 1 樹の果房すべてを覆ら作業 を袋状ネット区，市販の防鳥ネット（網目サイズ： $45 \mathrm{~mm}$, 幅 : $9 \mathrm{~m}$, 長さ：18 m, PE 防鳥網，東京戸張）を 2 張用い て 1 樹を完全に覆う作業を市販ネット区とし，両試験区の 作業時間を調査した。ささらに，両試験区の取付け時におけ る，1名当たりの脚立の使用回数（1 往復で 1 回）を調査し た。 また，両試験区の取付け時に打ける作業者の行動を観 察した。な拈，取付け作業は袋状ネット区，市販ネット区 ともに 4 名の作業者で各々 3 回行った.

\section{2. 袋状ネットの有無と鳥獣被害の発生推移および果実品 質への影響}

5 年生露地植方新短梢せん定栽培 “安芸クイーン’ およ び ‘ピオーネ’（一文字型整枝法）をそれぞれ 3 樹供試した. 試験区は，袋状ネットで果房を被覆する袋状ネット区，㧧 よび袋状ネットと市販ネットのいずれも被覆しない無被覆 区とし, 両試験区の鳥獣による食害発生の推移を調査した. 1 樹当たりの袋状ネット区と無被覆区の配置は，第 2 図の

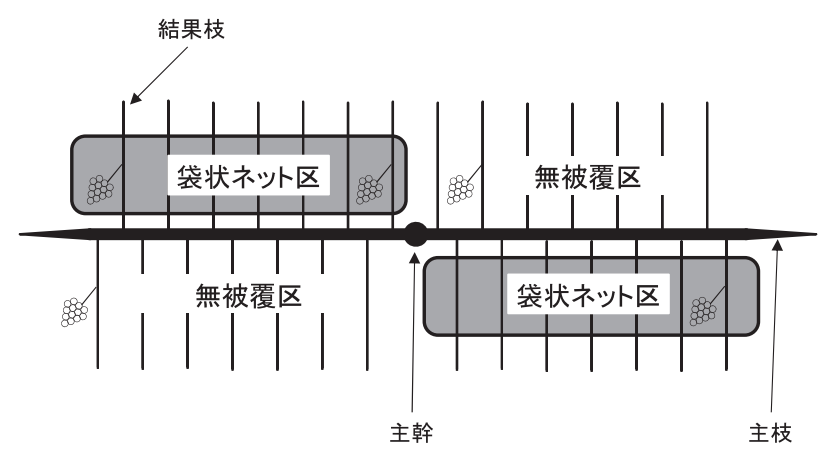

第 2 図鳥獣害調査における試験区の 1 樹当たりの配置図 
と扔りである. 両試験区の調査果房数は，“安芸クイーン’ では 3 樹の合計で袋状ネット区が 53 房, 無被覆区は 59 房, ‘ピオーネ’では袋状ネット区, 無被覆区ともに 69 房であっ た. 2008 年 7 月 8 日に両試験区を設置し, 果房の被害調查 は 7 月 15 日，29日，8月 12 日拈よび 25 日に行った. 被害 程度の調査は果房ごとに以下のように区分した.すなわち， 無 (被害なし), 小 (数粒の被害), 中 (房の欠損または半分 程度の被害)，大(残粒皆無)である。“安芸クイーン’打よ び ‘ピオーネ’ の収穫日は袋状ネット区，無被覆区ともに 2008 年 8 月 25 日であった. 収穫後, 1 区 1 樹につき 5 果 房, 合計 15 果房を供試し, 両試験区の果房重拉よび果粒重 を計測した. 各果房から 5 粒を選び, 果汁を採取し, 果汁 糖度扣よび酸度の測定に用いた。果汁糖度はデジタル式糖 度計（PR-100，アタゴ）で測定し, 酸度は自動滴定装置 (AUT-501，東亜電波工業）を用いて酒石酸当量として算出 した. 果皮アントシアニン含量はShiraishi ら（2007）の方 法により各々 6 回測定し, シアニジン -3-グルコシド当量 として算出した。 また, 袋状ネットの遮光率を明らかにす るため, 光量子計 (LI-189, LI-COR) を用いて, 袋状ネッ ト区抢よび無被覆区のブドウ果実袋内に打ける光合成有効 光量子束密度を各々計測した.

\section{結 果}

\section{1. 袋状ネットによる取付け作業の省力評価試験}

袋状ネット区括よび市販ネット区の取付怩作業時間を第 3 図に示した. 市販ネット区では, 1 樹当たり 15.8 分であっ たのに対し, 袋状ネット区では 5.2 分 (市販ネット区の 32.8 \%)となり，作業時間の有意な短縮が認められた。 また， 市販ネット区では， 1 樹に対する脚立の使用回数が 1 名当 たり平均 1.5 回であったのに対し, 袋状ネット区では 0 回 であった (データ略)。市販ネット区では脚立上での防鳥 ネットの展開や棚線への固定なぞ, 熟練を要する煩雑な作 業が多く，作業者 4 名が共同で作業を行う必要があった.

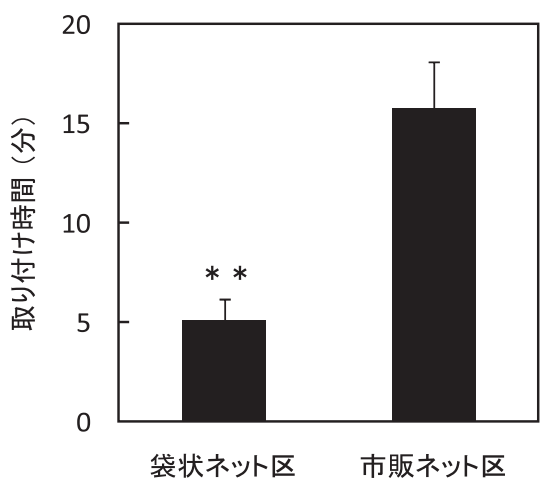

第3 図袋状ネット区拉よび市販ネット区に拈ける取付け作 業時間の比較

一文字型整枝樹 (片側 $6 \mathrm{~m}$ の 2 本主枝)の 1 樹当たりの 作業時間

**は $t$ - 検定により $1 \%$ 水準で有意差あり $(\mathrm{n}=3)$

これに対し，袋状ネット区では，すべての作業を棚下に括 いて 2 名 2 組で容易に行うことができた.

\section{2. 袋状ネットの有無と鳥獣被害の発生推移および果実品 質への影響}

鳥獣被害の発生推移を調査した結果，“安芸クイーン’で は無被覆区に抢いて，果実の着色開始期である 7 月下旬頃 から被害が見られ始め, 7 月 29 日の被害果房率は $15.3 \%$ （被害程度小：3.4\%，中：1.7\%，大：10.2\%）であった（第 4 図 A)。これ対し，袋状ネット区の被害果房は全くな かった. 8 月 12 日の無被覆区に打ける被害果房率は $32.2 \%$ （被害程度小: $1.7 \%$, 中 : 6.8\%, 大: $23.7 \%$ ) であったの に対し，袋状ネット区の被害果房は全くなかった。 8 月 25 日（收穫日）の無被覆区に打都被害果房率は 49.2\%（被 害程度中：3.4\%，大：45.8\%）であり，被害果房のほとん ぞが被害程度大であったが，袋状ネット区に打ける被害果 房率は 5.7\%（被害程度小：3.8\%，中：1.9\%）であった。 ‘ピオーネ’においても，無被覆区では着色開始期の 7 月下

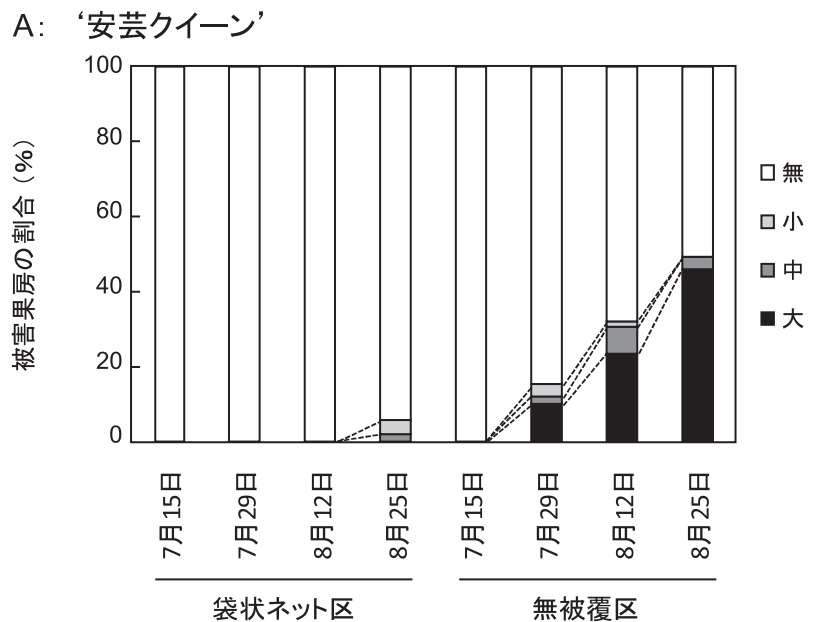

B: ‘ピオーネ’

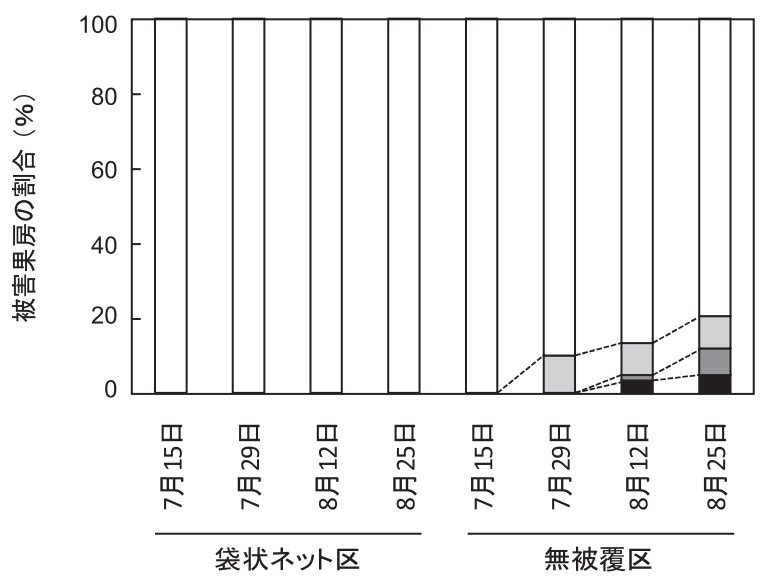

第 4 図 袋状ネット区および無被覆区における食害発生の推移 
A

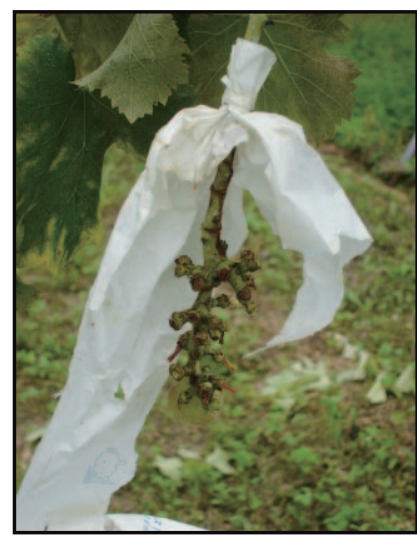

B

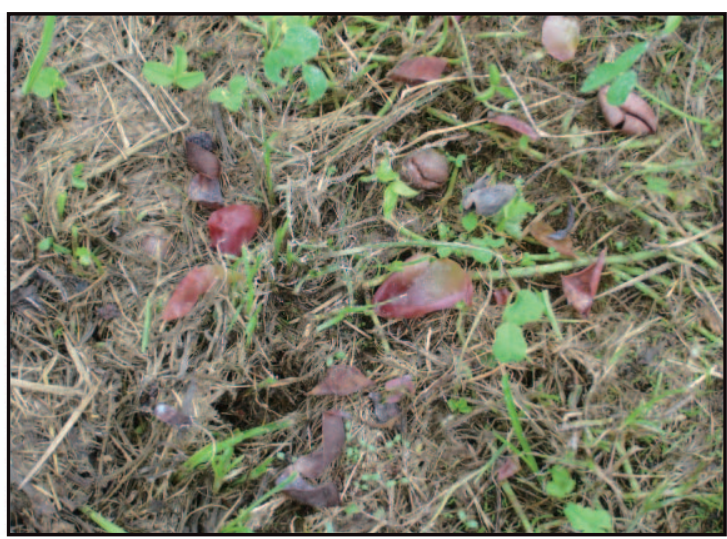

第 5 図 被害程度大の食害を受けた ‘安芸クイーン’果房（A）および被害果房直下に見られたブドウ果皮（B）

第 1 表 袋状ネット被覆がブドウ ‘安芸クイーン’の果実品質に及ぼす影響

\begin{tabular}{|c|c|c|c|c|c|}
\hline 処理区 & $\begin{array}{l}\text { 果房重 } \\
(\mathrm{g})\end{array}$ & $\begin{array}{l}1 \text { 粒重 } \\
(\mathrm{g})\end{array}$ & $\begin{array}{c}\text { 果汁糖度 } \\
(\%)\end{array}$ & $\begin{array}{l}\text { 果汁酸度 } \\
(\%)\end{array}$ & $\begin{array}{c}\text { 果皮アントシアニン含量 }{ }^{\mathrm{z}} \\
\left(\mathrm{mg} \cdot \mathrm{g}^{-1} \mathrm{FW}\right)\end{array}$ \\
\hline 袋状ネット区 & 378.7 & 13.5 & 21.3 & 0.48 & 0.23 \\
\hline 無被覆区 & 341.5 & 14.1 & 21.0 & 0.53 & 0.21 \\
\hline 有意差 ${ }^{y}$ & NS & NS & NS & $*$ & NS \\
\hline
\end{tabular}

$\mathrm{z}$ 平均值 $(\mathrm{n}=6)$

$\mathrm{y} *$ は $t$ - 検定により $5 \%$ 水準で有意差あり，また NS は有意差のないことを示す（n=15）

第 2 表 袋状ネット被覆がブドウ ‘ピオーネ’の果実品質に及ぼす影響

\begin{tabular}{|c|c|c|c|c|c|}
\hline 処理区 & $\begin{array}{l}\text { 果房重 } \\
(\mathrm{g})\end{array}$ & $\begin{array}{l}1 \text { 粒重 } \\
(\mathrm{g})\end{array}$ & $\begin{array}{c}\text { 果汁糖度 } \\
(\%)\end{array}$ & $\begin{array}{c}\text { 果汁酸度 } \\
(\%)\end{array}$ & $\begin{array}{c}\text { 果皮アントシアニン含量 }^{\mathrm{z}} \\
\left(\mathrm{mg} \cdot \mathrm{g}^{-1} \mathrm{FW}\right)\end{array}$ \\
\hline 袋状ネット区 & 453.1 & 13.8 & 20.5 & 0.57 & 1.44 \\
\hline 無被覆区 & 424.8 & 14.2 & 21.0 & 0.53 & 1.40 \\
\hline 有意差 ${ }^{y}$ & NS & NS & NS & $*$ & NS \\
\hline
\end{tabular}

$\mathrm{z}$ 平均値 $(\mathrm{n}=6)$

$\mathrm{y} *$ は $t$ - 検定により $5 \%$ 水準で有意差あり，また NS は有意差のないことを示す（n=15）

旬頃から被害が見られ始め, 7 月 29 日の被害果房率は 10.2 \%（すべて被害程度小）であった（第４図B）。しかし，そ の後の被害程度は ‘安芸クイーン’ と比較して低く推移し, 8 月 25 日に扣ける被害果房率は $20.3 \%$ （被害程度小：8.5 \%, 中 : $6.8 \%$ ，大 : 5.1\%）であった。袋状ネット区では, 8 月 25 日に颃いても被害果房は全くなかった。被害果房を 観察すると, 被害程度中〜大の果房の多くは果実袋が大き く破れ，果皮が地上に残されていた（第 5 図 A, B). この 特徵は, 近年被害が増加傾向にあるハクビシンやアライグ マなどによる食害（古谷，2009）に類似していた。 また， 供試樹にカラスが飛来し，果実袋や果房を食害する様子が 目視で確認され，鳥類による被害の特徵である果実袋や果 房がくちばしでつつかれた跡が，被害程度小〜中の一部で みられた。従って，本試験地に打ける被害の中心は，八ク ビシンやアライグマなどの中型動物，およびカラスなどの 鳥類によるものと推察された.

“安芸クイーン’ および ‘ピオーネ’の収穫時に打ける果
実品質を第 1 および 2 表に示した．袋状ネットの遮光率は 26.3\%であったが (データ略)，果房重，1粒重，果汁糖度 扎よび果皮アントシアニン含量は，両品種とも処理間で有 意差は認められなかった。果汁酸度は，“安芸クイーン’で は袋状ネット区で $0.48 \%$ ，無被覆区で $0.53 \%$ であったのに 対し, ‘ピオーネ’では袋状ネット区で $0.57 \%$, 無被覆区で $0.53 \%$ となり，両品種とも処理間で有意差が認められた.

\section{考察}

短梢せん定栽培ブドウを対象とし，着脱の省力化と高い 防鳥獣効果を目的とした袋状ネットを考案した（東ら, 2009). 本ネットの主な特徵は, ネットを袋状にすることで 果房のみを保護する点，棚下にネットを設置するため，脚 立の使用を必要としない点である（第 1 図 A，B）。これに より，袋状ネットの取付けに要する時間は市販ネット区の $32.8 \%$ となり，作業時間が大幅に短縮した（第 3 図）。果樹 の鳥獣害の防止にかかる作業の省力化を目的とした技術 
は，これまでにもいくつか考案されている（萩原ら，2000； 岩瀬ら， 2000; 米田ら，2005). しかし， これらはネットを 固定するための新たな施設と労力を要する上, 樹高や主枝 長など,樹形を施設に合わせる必要があるため, 園地によっ ては適用が困難な場合がある。 また, 樹体の周囲を防鳥ネッ トで被覆するため, 栽培管理時にネットをたぐり上げる必 要がある点, スピードスプレーヤー（SS）や草刈り機など の使用が困難な点など，設置後の作業性に問題がある. こ れに対し, 袋状ネットの設置は容易で, 新たな施設や資材 などを必要としないため, 設置にかかる労力の軽減効果が 高いと考えられる。 また, 花穗整形などにより, 穂軸が長 くとれる品種を用いた短梢せん定栽培であれば，本試験で 使用した一文字型整枝以外にも $\mathrm{H}$ 型整枝や WH 型整枝な ど，様々な樹形に適用することが可能であり，傾斜地など の立地条件でも使用できることから，袋状ネットの適用範 囲は広いと考えられる. 設置後の作業性は, ネットが棚下 の限られた範囲に固定されるため, 機械を用いた作業の妨 げにならず，慣行通りの SS や草刈り機の使用が可能であ る。 また，本試験における取付け時間の試験では，2名 2 組で袋状ネットの取付けを行ったが，1名でも取り付けが 可能であった，さらに，ネットの接合部に面ファスナーを 用いたことで，果房の栽培管理，成熟状況の確認，および 収穫の際には，対象となる果房近傍の接合部のみを開き， 容易にそれらの作業を行らことができた. 収穫後の取り外 しは, ネットの引っかかりなどによる枝葉の損傷も無く容 易に完了し, 取り外し後は折り畳めるため収納が容易で, 翌年の再利用が可能であった。 このように，袋状ネットは 鳥獣害の防止にかかる作業の省力化につながる, 多くの利 点を有すると考えられた。

“安芸クイーン’ 拈よび ‘ピオーネ’を用いて，袋状ネッ トによる防鳥獣効果を調査した結果, 無被覆区では両品種 とも深刻な鳥獣害を受けたのに対し, 袋状ネット区ではほ とんど被害を受けなかった（第 4 図 A, B).さらに，本試 験の翌年に ‘ピオーネ’ 3 樹の果房すべてを袋状ネットで 被覆したところ, 被害果房の発生はみられず, 果実品質へ の影響も確認されなかった (データ略).このことから, 袋 状ネットには高い防鳥獣効果があると考兄られる. しかし, ‘安芸クイーン’では袋状ネット区に打いても被害がわずか に認められ，鳥獣害を完全に防止することはできなかった (第4 図 A). 星川ら（1982）はブドウおよびナシ園を対象 として，防鳥ネットに用いる網目サイズを検討し，ムクド リなどの比較的大きな鳥を対象とした場合は $30 \mathrm{~mm}$ 以下, スズメなどの場合は $24 \mathrm{~mm}$ 以下のネットが必要であるとし ている，袋状ネットに用いる網目サイズと防鳥獣効果との 関係については調査していないが，本試験で使用した袋状 ネットは $4 \mathrm{~mm}$ と十分に細かいため, 網目サイズは今回の 被害の原因ではないと考えられる. 一方, 被害を受けた果 房を観察すると, 果房の一部とネットが密着しており, 鳥 獣がネットの外側から果房に接触できる状態であった.
従って，本試験における袋状ネットでの被害を回避するに は，今後ネット全体もしくは一部に適当な剛性を有する資 材，例えば針金，プラスチック，グラスファイバーなどの フレームを組み込むなどして，袋状に被覆した時に，ネッ トと果房間に一定の距離を保持できるようにする必要があ ると考えられた。 また，本試験で使用した袋状ネットでは， 設置後の風の影響によるネットの摇れ，それに伴ら果実の 損傷などは確認されなかった。 しかし，ネットの目合いを さらに細かくした場合や，設置場所の気象条件によっては 影響を受ける可能性があることから，ネットの摇れ防止に ついても今後検討する必要がある.

“安芸クイーン’扎よび ‘ピオーネ’の無被覆区では，い ずれも深刻な鳥獣害を被った。しかし，両品種が隣接して 植栽されていたにも関わらず，その被害程度は大きく異 なった（第 4 図 A, B). ‘ピオーネ’よりも ‘安芸クイーン’ の被害が大きい傾向は，供試樹において着房を開始した 2006 ２008 年まで一貫していた. ナシに拈いて，ムクド リによる果実の被害程度には品種間差があることが報告さ れている（坂本，1981）。これは，被害程度が鳥獣の選好度 の影響を受けることを示している.ブドウで同様の調査が 行われた例はないが，本試験に拈いても，果実の食味や香 りなどの品種間差により鳥獣の選好度に差が生じ, 両品種 での被害程度の差となった可能性がある.

一般に着色系ブドウは，光への反応性の違いから，直光 着色品種と散光着色品種に大別されており（土屋，1980）, 品種によって着色は光条件の影響を大きく受ける．本試験 に打ける袋状ネットの遮光率は 26.3\%であったが, “安芸ク イーン' 抽゙ ‘ピオーネ’ ともに無被覆区に比べて着色 に大きな影響は認められなかった（第 1，2表）。一方，内 藤ら（1984）は ‘巨峰’ に打いて，自然光の 30\%程度の遮 光でも，年によっては着色が抑制されることを報告してい る. 着色に対する光条件の影響の大きさは，その年の環境 条件, 栽培条件によって変動すると考兄られる（内藤ら, 1984）。従って，品種や環境，栽培条件によっては，袋状 ネットの使用により着色が抑制される可能性を否定できな い. 本試験では, 着色不良の生じやすい ‘安芸クイーン’ に打いても袋状ネットの使用による着色不良は認められな かったため，着色への影響は小さいと考えられるが，遮光 による着色抑制を確実に回避するためには，今後，遮光率 がさらに低いネットの使用を検討する必要がある。また， 果汁酸度は‘安芸クイーン’ では無被覆区と比較して袋状 ネット区で減少したのに対し, ‘ピオーネ’では袋状ネット 区で増加して扣り，袋状ネットの被覆による酸度への影響 は判然としなかった. 今後, 試験対象とする品種やネット 資材の種類を増やすなどの検討を重ね，袋状ネットの被覆 が酸度に与える影響を明らかにする必要がある。

近年, ブドウ産地では鳥害に加え, 八クビシンやアライ グマなどによる獣害が増加しており，大きな务威となって いる．このことから，簡便でかつ多様な鳥獣に対応可能な 
防止技術の確立が強く求められる. 袋状ネットは, その構 造が単純であることから取り扱いが簡便な上，対象とする 鳥獣によってネット強度の強化など, 様々な応用が可能で ある. 今後, さらなる検討を行うことにより, 袋状ネット は簡便で効果の高い防鳥獣技術として, ブドウ短梢せん定 栽培に寄与できるものと考光る。

\section{摘 要}

短梢せん定栽培ブドウを対象とし，着脱作業の省力化と 高い防鳥獣効果を目的とした袋状ネットを考案した. 本 ネットの主な特徵は, ブドウ果房の久が覆われるようネッ トを袋状にすることで，短時間で多数の果房が一度に保護 される点, 棚下にネットを設置するため, 脚立の使用を必 要としない点である. これにより, 袋状ネットの取付けに 要する時間は市販ネット区の $32.8 \%$ となり，作業時間が大 幅に短縮した。また，“安芸クイーン’扎よび“ピオーネ’ を用いて袋状ネットによる防鳥獣効果を調查した結果, 無 被覆区では両品種とも深刻な鳥獣害を受けたのに対し, 袋 状ネット区では活とんど被害を受けなかった。ささらに，袋 状ネットの設置による果実品質への悪影響は認められな かった．以上のことから，袋状ネットの利用により，鳥獣 害対策にかかる作業の省力化，拈よび高い防止効果が得ら れることが示された。

謝 辞 本研究の実施に当たり, 調査の補助をしていた だいた当拠点技術専門員の元川 晃氏, 高岡 浩氏, 勝田 新一氏，ならびに契約職員の森重豊子氏，池田純子氏，梅 花鏡子氏，島津文子氏，中原利子氏に感謝致します。

\section{引用文献}

東 暁史 - 薬師寺 博 - 児下佳子. 2009. 果房や果実の保 護方法, 果房や果実の保護ネット. 特許出願 2009292711.

古谷益朗. 2009. 八クビシン・アライグマ一おもしろ生態 とかしこい防ぎ方一。 p. 14-23. 農文協. 東京.

萩原利喜一・岩瀬茂夫 ・ 潮田伸雄 - 横田 武 - 小松崎昭男 飯泉斗志雄 - 土居克人 - 宮本和美 - 飯島正博 - 稲葉伸 一・石井健一・青葉裕二・寺田恒夫・鈴木勝征. 2000 . 果樹のための防鳥方法. 特許公開2000-69863.

星川三郎・三好恒和・村岡邦三・川口松男. 1982. 果樹の 鳥害防止について．群馬園試研報． 10: 30-50.

池内 温・荻原洋晶・大政義久 ・窪田聖一・大西論平. 2005 . カンキッ園に扮ける鳥害防止に関する研究. (第 2 報) 機器や資材利用による鳥害防止効果. 愛媛果樹試研報. 19: 37-55.
岩瀬茂夫・萩原利喜一・潮田伸雄・横田 武・小松崎昭男・ 飯泉斗志雄・土居克人・宮本和美・飯島正博・稲葉伸 一・石井健一・青葉裕二・寺田恒夫・鈴木勝征. 2000 . 果樹のための防鳥用パイプハウス. 特許公開 200069862.

前川佳史・徳田哲男・黒川秀一・宇賀神 博・岸田孝弥・ 倉林 武・黒田 勲・永田久雄・丸山仁司. 1998．消 費生活用製品の事故原因に関する研究.（その3）高齢 者の脚立作業による実験的研究. 人間工学. 34 : 234235.

松岡 茂. 1989. キジバトに対するマネキン人形の顔の忌 避効果. 日鳥学誌. 38: 79-92.

内藤隆次・山村 宏・池上研二 ・井秀一 ・三島啓子. 1984. ブドウ巨峰の着色に及ぼす光度の影響. 島根大農研報. 18: 8-15.

中村和雄・岡ノ谷一夫. 1992. 音声の利用による鳥害防除. 日本音響学会誌. 48: 577-585.

中村和雄・横山広行. 1995. 臭い物質パラジクロルベンゼ ンのドバトに対する忌避効果. 日鳥学誌. 44: 13-19.

農林水産省. 2008. 鳥獣による農林水産業等に係る被害の 防止のための特別措置に関する法律. 平成 20 年 2 月 20 日農林水産省令第 7 号.

農林水産省生産局．2009．果樹の生産関係．果樹農業に関 する資料. p. 81 .

小川孝郎．2001．草生栽培で生かすブドウの早仕立て新短 梢栽培. p. 20-21. 農文協. 東京.

坂本堅五. 1981. 果樹への鳥害に関する調査一特にムクド リによるナシの被害を中心として一。応用鳥学集報. 2: 53-57.

Shiraishi, M., M. Yamada, N. Mitani and T. Ueno. 2007. A rapid determination method for anthocyanin profiling in grape genetic resources. J. Japan. Soc. Hort. Sci. 76: 28-35.

Shirota, Y., M. Sanada and S. Masaki. 1983. Eyespotted balloons as a device to scare gray starlings. Appl. Ent. Zool. 18: 545549.

鈴木勝征・吉永勝一. 1999. 果樹栽培に拈ける鳥獣被害及 び防止法の現状．果樹試報. 32: 39-64.

土屋長男. 1980. 実験葡萄栽培新説 (増補版)。p. 256-258. 山梨県果樹園芸会. 山梨.

山梨県果樹園芸会. 2007. 葡萄の郷から一おいしいブドウ のできるまで一. p. 41-47. 山梨県果樹園芸会. 山梨.

米田健一・井上雅央・一ノ瀬浩史・高藤晃雄. 2005 . ブド ウ栽培に打ける簡易防鳥ネット導入による鳥害回避の 試反。応動昆. 49: 245-250. 